Orlova, L.Y. (2020). Ancient Novgorod civil society. Past and present in the philosophy of social development. Past and present in the philosophy of social development. Collection of Scientific Articles. European Scientific e-Journal, 2 (2), 74-86. Hlučín-Bobrovníky: “Anisiia Tomanek” OSVĆ.

Орлова, А.Я. (2020). ГражАанское общество Аревнего Новгорода. Past and present in the philosophy of social development. Collection of Scientific Articles. European Scientific e-Journal, 2 (2), 74-87. Hlučín-Bobrovníky: "Anisiia Tomanek" OSVČ.

DOI: $10.47451 /$ his2020-09-002

EOI: $10.11244 /$ his2020-09-002

The paper is published in Crossref, Internet Archive, Google Scholar, Academic Resource Index ResearchBib, JGate, ISI, CiteFactor, ICI, eLibrary databases.

Lyubov Y. Orlova

Doctor of Social Sciences, Full Professor Peter's Academy of Arts and Sciences (St Petersburg) Vice-President of the regional Non-Profit Foundation of the Supporting of St Petersburg Science, Culture and Sports St Petersburg, Russia E-mail: orlova-1703@inbox.ru

\title{
Ancient Novgorod civil society
}

\section{Abstract:}

Ancient civilization, of which civil society is certainly an integral part, had a huge impact on the subsequent development of civil societies around the world. The romanization of 'barbarian' peoples, which began in the heyday of the Roman Republic, absorbed many of the principles and organizational forms of Roman civil society. Western European civil society of the 17th and 18th centuries and our modern civil society as a reference turned to the ancient civil society. In article various approaches to understanding Ancient Novgorod civil society are considered, is analyzed democratic principles in activity of the Novgorod republic. Th author concludes that the Ancient Novgorod civil society not only enriched the world practice but also created an original type of civil society. One of the Russian idea's representatives, G. Fedotov, who developed the theory of the Orthodox democratic state, believed that this had already happened once in Russian history, meaning "the creation of a unique Orthodox democracy in Novgorod"

\section{Keywords:}

the Novgorod Republic from 12th to 15th centuries, a civil society, veche, Veche democracy, the prince, a national home guard, birchbark reading and writing, masterful, merchants, trade.

\section{Аюбовь Яковцевна Орцова}

профессор, Аоктор социологических наук

АкаАемия искусств и наук им Петра Великого

Вице-президент регионального фонда подлержки науки, культуры и спорта

Санкт-Петербург, Россия

E-mail: orlova-1703@inbox.ru 


\section{ГражАанское общество Аревнего Новгорода}

\section{Aннотачия:}

Аревняя цивилизация, неотъемлемой частью которой, безусловно, является гражАанское общество, оказала огромное влияние на последующее развитие гражАанского общества во всем мире. Аатинизация «варварских» народов, начавшаяся в период расцвета Римской республики, вобрала в себя многие принципы и организационные формы римского гражданского общества. Западноевропейское гражАанское общество 17-18 веков и наше современное гражданское общество в качестве ориентира обратились к античному гражданскому обществу. В статье рассматриваются разАичные подходы к пониманию Аревнего гражАанского общества, анализируются Аемократические принципы в Аеятельности Новгородской республики. Автор приходит к выводу, что гражАанское общество Аревнего Новгорода не только обогатило мировую практику, но и созАало самобытный тип гражАанского общества. ОАин из преАставителей русской идеи, Г. ФеАотов, разработавший теорию православного Аемократического государства, считал, что это уже однажды произошло в российской истории, что означает «созАание уникальной православной демократии в Новгороде».

\section{Kлточевъе слова:}

Новгородская республика XII-XV вв., гражданское общество, вече, вечевая демократия, князь, народное ополчение, берестяная грамота, мастерство, купечество, торговця.

\section{Introductions}

Ancient civilization, of which civil society is certainly an integral part, had a huge impact on the subsequent development of civil societies around the world. The romanization of 'barbarian' peoples, which began in the heyday of the Roman Republic, absorbed many of the principles and organizational forms of Roman civil society. Western European civil society of the 17th and 18th centuries and our modern civil society as a reference turned to the ancient civil society.

How did civil society develop in Russia? On the one hand, it could not develop in absolute isolation from the path already laid by mankind and, naturally, it absorbed historical experience, and on the other hand, the identity of the development of the entire Russian society - left its mark on the formation of civil society. The historical roots of the identity of Russian civil society will be analyzed in the following data. In the same article, we will discuss in more detail the ancient Novgorod civil society.

\section{Historical characteristics Ancient Novgorod civil society}

In the Novgorod Republic of the 11-15th centuries, a rather unique open-type civil society developed, largely ahead of the Western European societies of that 
period.

In addition, in other Russian lands during this period there was a period of regression associated primarily with the invasion of the Golden Horde. In March 1238, in a campaign against Russia, Batu did not reach the Novgorod lands. Not having reached a hundred versts to Novgorod, the Tatars stopped fearing, according to some reports, the approach of spring flooding of rivers, melting swamps, and went to the south-east, on the steppe (Tikhomirov, 1964) [1]. At the end of 1240, Kiev was taken and destroyed. A long, dark period begins in the history of Russia. Different assessments of the Tatar-Mongol invasion of Russia are given in modern literature. It is alleged, for example, that in the Russian Chronicles, events distort, exaggerate in the description of the massacres and devastations, which were carried by the conquerors. However, the evidence of written sources both in Russia and abroad, as well as data from archaeological excavations, do not support these hypotheses. The Russian land was devastated and plundered. The natural process of historical development of Russia was interrupted. This fully applies to the development of civil society, the contours of which began clearly to appear after the formation of Russian Justice (or Russian Pravda) in the 11th century [3]. Therefore, it is of particular importance to consider the Novgorod Republic, which throughout the period of the Tatar-Mongol invasion and after it, remained the only center of democratic development in Russia until the conquest in 1471-1478 by the Moscow Prince Ivan III Vasilyevich.

It should be noted that elements of civil society have emerged in Novgorod not only because of the specific historical situation discussed above, but also because of the current geopolitical and economic situation. Novgorod owned a huge territory of North-Western Russia - from the Gulf of Finland to the Urals and from the Arctic Ocean to the upper Volga. Novgorod was at the beginning of the famous way From the Varangians to the Greeks, which played an extremely important role. Novgorod always had strong economic ties with Western Europe drawing ideas and many organizational forms of self-government of cities, especially the Hanseatic League, from it.

A strong focus of the entire economic turnover of the Novgorod land appeared to be involved in the life of the main city everything that were picked up, and on the other hand, caused an active part of the Novgorodians in the trade-industrial life of the suburbs of the whole earth. We constantly find references to Novgorod merchants in the suburbs and volosts, and the jurisdiction of merchants in Novgorod indicates a broad development of participation of Novgorodians in local life, where they were driven by commercial and trading interests. Deep domestic ties supported 
the unity of the Novgorod region and the predominance of the main city in it (Presnyakov, 1993).

In the first decades of the 11th century, Novgorod acted as a fairly consolidated community. The outlines of the Novgorod Veche, which had the necessary power to resist the Prince on occasion and direct his activities in accordance with the interests of local society, are outlined in relief. The social energy of Novgorodians was mainly absorbed by the struggle to reduce dependence on Kiev. It is remarkable that they managed to make Prince Yaroslav an instrument of this struggle for some time. There we observe the first manifestations of new relations between Novgorod and the princely power, which previously stood guard over the interests of the Kievan Grand Duke, but then had to give them up in favor of Novgorod. There were changes in Posadnik's management. There were sprouts of a new type of such management that coexisted with the Principality and was organically connected with the Novgorod community. There were prerequisites for the election of local posadniks to replace those sent from Kiev (Froyanov \& Yudin, 1980) [2].

The designated time should include the completion of the formation of statehood in Novgorod characterized by a full set of inherent features: the presence of an even stronger public power, the rudiments of 'taxation' and the placement of the population on the territorial principle. The subsequent history of Novgorod statehood was associated with the strengthening and improvement of public power, the branching of the tax system, and the deepening of the territorial foundations of settlement (Froyanov \& Yudin, 1980) [2].

The political system of the ancient principalities was characterized by "a mixed form of government, in which two elements participate, namely the monarchical represented by the Prince, and the popular, democratic one represented by the Veche" (Sergeyevich, 1973). The whole question is what relationship between these two elements took place in a particular land in a particular historical period.

The Prince in Novgorod was always secondary to the city. His dependence on the people of Novgorod were always significant. They could banish a Prince, summon another to the princely table at their own discretion: the change of princely power occurred 58 times from 1095 to 1304. An event of all-Russian significance was the decision of the Novgorod Veche in 1136. The Novgorodians drove Prince Vsevolod Mstislavovich to Pskov. The new Prince was invited not from the Kievan land, but from the ruling house of Chernihiv. Novgorod coins did not depict a Prince, but the personification of Novgorod - Sofia (an angel representing wisdom) and the inscription: 'Veliky Novgorod', while the coins of Russian principalities always had the names of princes. Along with the princely seals, in Novgorod during 
the excavation, seals of the Novgorod Posadniks, tysyatskys (thousandmen), tiuns, and archbishops were discovered. There were also seals of individual boyars, who obviously held public office.

The powers of the Novgorod Prince differed significantly from those of the princes of other Russian lands. The main duty of the Prince in Novgorod, as elsewhere, was the duty of the supreme judge, in the performance of which he considered the laws that were in force in the city. However, the princes were constantly changing: they came from distant countries, from regions of Kiev, Volyn, Smolensk, Chernihiv, Suzdal. The alien princes had no idea of the customs of Novgorod, just as the Novgorodians did not know the customs of other Russian regions: hence there was incessant misunderstandings in the princely court. To ward off such inconveniences, Novgorodians demanded of every new Prince to judge always in the presence of officials elected from the citizens, familiar with all customs and relations of the country, "And no pasadnik, you, the Prince, has not to judge." (Solovyev, 1960)

In the arsenal of Novgorodians enriched with another invention, with help of which they resisted the claims of the Great Kievan princes: 'nurturing' or education, raising princes from a young age. Having taken to themselves by agreement with the Grand Prince some boy Prince, the Novgorodians tried to educate the younger Rurikovich in the spirit of their customs and mores, in order to make him a ruler, who ruled in accordance with the interests of Novgorod society. Noting the emergence of a new system of 'nurturing' the Prince, B.A. Rybakov writes, "Novgorod invited a young prince from the family of an influential Prince and accustomed him to his boyar orders from an early age." (Rybakov, 1982) [3]

That is why, I.Y. Froyanov rightly observes, "feeding the Prince is, in fact, a way to transform the power of the Governor, imposed from outside, into the local princely power of the Novgorod community. Of course, this transformation was not complete. However, we cannot deny certain of its results." (Froyanov \& Yudin, 1980) [2] A striking example of this approach of the Novgorod community can be Mstislav, the son of Vladimir Monomakh. He was brought to Novgorod in 1088 when he was 12 years old. In 1093, he moved to Rostov and then to Smolensk. In 1095, the Novgorodians again took the Prince to themselves. In total, Mstislav reigned in Novgorod for almost 30 years. Novgorodians valued him primarily because they 'nurtured' him. The Tale of Bygone Years tells that in 1102, Svyatopolk, the Grand Prince of Kiev, planned to withdraw Mstislav from Novgorod and put his son there. The envoys of the Novgorod Veche prevented this saying that they had all the rights to Mstislav, and the Grand Prince had to agree to this. 
In the social and political life of Novgorod, the Veche had great importance. It was the supreme authority, elected a Posadnik, a tysyatsky (thousandman), a Bishop, declared war, made peace, and tried the highest officials. Artisans and small traders had their own self-governing headmen. Novgorod was divided into five ends, and the ends, like the streets, had their own Veche, their elected elders. Numerous finds of birch bark letters in Novgorod suggest that literacy was widespread not only among the nobility, but also among ordinary citizens.

Gradually, the principles and organizational forms of management of the Novgorod Veche were formed. Novgorod management was built in connection with the definition of the relations of the city to the Prince. These relationships were defined by contracts. Because of this, political center of gravity in Novgorod had to move from the Prince's court to the Assembly Area in the local society environment. That is why, despite the presence of the Prince, Novgorod was actually a city Republic in specific times.

Analysis of the emergence and functioning of the national Veche in the Ancient Russian lands is given by many Russian historians. V.I. Sergeevich considers the Veche system, apparently, of the same type as observed in the 11th and 12th centuries existing since time immemorial. In his view, it had strongly been developed since the 9th and 10th centuries. Already in the treaties with the Greeks, he finds a manifestation of the major role of the Kiev Veche. The treaty of 945 was signed by the ambassadors "from Igor, the Russian Grand Prince, and all the people of Russian Land". V.I. Sergeyevich believes that the words of the last agreement on the arrival of the ambassador "to Russian Prince Igor and his people", about the oath "Many of us were baptized" and unbaptized Russia refers to the entire population of Kiev, and does not imply "any close group of people dependent on Igor" (Sergeyevich, 1973).

V.I. Sergeyevich sees the main support of the Veche force in the military significance of the people's militia. Objecting to the opinion of the unlimited power of princes, he observes, "As long as all the people were armed, as long as the army did not specialize and did not enter into the Prince's management, absolute power could not be formed; the people formed the main force of the princes, who therefore had to enter into an agreement with them" (Sergeyevich, 1973) In his opinion, this organization of city parishes was formed by subordinating the surrounding population to the enterprising founders of cities, who also built suburbs to 'protect' their acquisitions. V.I. Sergeevich imagines them mixed groups, which "could include people of different Slavic tribes and even foreigners, Chud and Merya could connect with the Slavs." (Sergeyevich, 1973) 
If we join this point of view on the formation of a national Veche for the entire Ancient Russian land, then we will find a number of confirmations of this in relation to Novgorod related to its geopolitical and economic position, which were discussed above. In the case of Novgorod, the assumption of joining the Veche of foreigners seems very likely that at the same time, it indicates the broad social base of its civil society.

Another approach is contained in the works of V.O. Klyuchevsky. His theory of the commercial origin of cities in Russia is well known. The origin of urban areas is based on "the emergence of the oldest cities in Russia with commercial and industrial districts that stretched to them". And this phenomenon can be attributed to the 8th century, and its origin is presented as follows: the Eastern Slavs settled along the Dnieper and its tributaries in lonely fortified courtyards, where trappers and bortniks converged for a guest house, and the points themselves were called churchyards; such small rural markets were drawn to larger ones that appeared on particularly brisk trade routes; from these large markets, which served as intermediaries between native Industrialists and foreign markets, our oldest cities grew" (Kliuchevsky, 1906) as A.E. Presnyakov rightly notes, "This is the first stage of Russian historical development. It is important in the historical theory of Klyuchevsky because it serves as an explanation of the nature of the social elements that created the influence of the Veche and guide Veche life: this is the commercial and industrial aristocracy, representatives of commercial and industrial capital." (Presnyakov, 1993)

With the growth of cities, where foreign military-industrial people accumulate (9th century), with which cities organize their military force, using it not only to fight an external enemy but also to subdue the surrounding population of their tribesmen, there is an urban area-the "first political form of Rus", the predecessor of the secondary form - the Varangian reigning.

Power in this "the first political form" was not, however, Veche, folk. "In the 9th century, the administration of the city and the region was concentrated in the hands of the military foreman, military chiefs of the main city, tysyatsky (thousandmen), sotsky(hundredmen), etc., who came from among the commercial city nobility. With the advent of the princes, this urban aristocracy gradually became part of the princely squad, the class of princely husbands, or remained in place without government business.

The military administration of cities by personnel, which had previously been, perhaps, elective, or at any rate native in origin of its personnel, now became a command-and-service Department, passed into the hands of princely men by 
appointment of the Prince. As for the decline of the authority of princes, owing to the strife began again to climb the main regional cities; however, political power in these cities was, instead of the missing government by the nobility of the entire urban mass gathered in the chamber. Thus, the national Assembly of the main regional cities was the successor of the ancient urban commercial and industrial aristocracy." (Kliuchevsky, 1906).

Finally, "the third epoch of the Veche assemblies (from 9th to 11th centuries) was the epoch of the complete separation of this form of power into an independent one (as an assemblies of ordinary citizens) and the full development of its rights. It coincides with the time of the final establishment of the power of the older cities." (Sergeyevich, 1973)

\section{The thoughts of Russian historians about Veche place in Ancient Novgorod civil society}

Despite different approaches to understanding the genesis of Veche, its evolution seems similar to representatives of the national historical school, who developed this problem (V.O. Klyuchevsky, M.F. Vladimirsky-Budanov, V.I. Sergeevich, A.E. Presnyakov). The prehistoric ancestor of Veche meetings were tribal gatherings, meetings that existed among the Slavs at the early dawn of their history, according to Procopius (6th century): the Slavs "have lived in in people's power since ancient times; happy and accidents have called them to a General Assembly", and Mauritius, which lasted at the Vyatichs, where urban life was poorly developed, until the 12th century (Vladimirsky-Budanov, 1900). The force that the princes had to reckon with from the first steps was the organization of special management of urban areas that was created on the eve of their appearance. "The system of Zemstvo administration (more ancient than the princely one) was based on the numerical division of society, as the whole state was a thousand, and the older cities in the province were divided into hundreds and tens, so the central ruler was tysyatsky (thousandman), and the subordinate sotskys (hundredmen) and desyatskys (tenmen)." (Vladimirsky-Budanov, 1900)

M.F. Vladimirsky-Budanov imagines the process of development of the Veche from the tribal assembly to the city one so that in the period from 9th to 10th centuries, "to solve cases, the best people of the entire land come together in the senior city and discuss Zemstvo issues in the presence of the citizens of this city" calling such a transitional phenomenon by "the General Duma combining two future institutions - the boyar Duma and the Veche" (Vladimirsky-Budanov, 1900).

What was the role of the Novgorod Veche as a body of supreme power? We 
can present the analysis of A.E. Presnyakov, who considers various points of view on this issue. He wrote that "Syromyatnikov's attempt (Muravyev \& Syromyatnikov, 1973) to establish two points in the development of Veche competence is very interesting. Initially, two functions of the Veche embraced the entire sphere of state government: legal education, the court, management, the role of the Veche as a 'trustworthy witness' certifying the actual issues of a dispute about law, and etc. Later, gradually, the functions of the supreme administration remain for the Veche: the calling and expulsion of princes, a number of them, control over the administration, the supreme court, issues of war and peace, international treaties, legislation. This idea can be recognized as correct if the first stage of the Veche is understood as the people's meetings of the oldest territorial unions - vervi, hundreds, etc. However, the historically known city Veche as the supreme authority of the parish can only be characterized by the functions of higher management.

A question of frequency of meetings of the Veche is related with this. M.F. Vladimirsky-Budanov considers it to be probable believing that the annals talking very often on the marketplaces connected with any revolution, passed ordinary peaceful meetings to address current affairs (Vladimirsky-Budanov, 1900). He needs to allow for the frequency of Veche meetings, because he claims that "Veche deals with the current affairs of the court", to confirm which he cites examples from the late practice of Novgorod and Pskov - the princely and posdnik court at the Veche. The conclusion is very artificial and unfounded.

On the contrary, it is impossible not to agree with V.I. Sergeevich's denial of "the very idea of the periodicity of Veche meetings" (Sergeyevich, 1973) and with his explanation that "there was no reason for periodic meetings, since the Veche did not deal with any current issues of legislation, court and management". However, we note that we are talking about the Russian Veche in general. This is what A.E. Presnyakov himself says when, in support of the above-mentioned point of view, he refers to the opinion of M.F. Vladimirsky-Budanov stipulating that, of course, this did not apply to Novgorod and Pskov.

In fact, the legislative, legislative, and judicial activities in other Russian principalities were in the domain of princely law, while this type of activity in Novgorod was either the domain of its Veche, or was carried out jointly by the Prince and the Veche. Therefore, the conclusion of A.E. Presnyakov that "the Veche did not centralize the administration of the parish without having outside the princely administration and organs for any of its administration" (Presnyakov, 1993), cannot be attributed to the Novgorod Veche. The Veche was called, depending on the circumstances, by the prince, posadnik, tysyatsky (thousandman), and met at the call 
of the Veche bell or by fellow citizens. The question of the mechanism of functioning of the Novgorod Veche is extremely important for understanding the essence of this civil society.

Indeed, the documents at our disposal do not indicate any own administration of the Veche, which would allow us to carry out the management process independently. Therefore, only the option of self-government remains. The Novgorod Veche was a rather complex self-governing body consisting of selfgoverning units. The main such unit was the hundred with its own internal selfgoverning organization. The main significance of the hundred was in its role as the center of the entire way of life, legal and administrative, economic and religious. Hundred was a judicial district, the place of judicial meetings was in its center. It was a union for the protection of the Zemstvo world. Duties were being deployed with hundreds. They were the main judicial and administrative institution for the urban population and at the same time, a form of organization of its commercial and industrial population in Novgorod (Presnyakov, 1993).

However, the hundred was not the smallest administrative part of the city: it was subdivided into streets, each of which also formed a special local world that enjoyed self-government with its own street chief. On the other hand, hundreds formed larger alliances, or 'ends'. Each 'end' of the city consisted of two hundred. At the head of the 'end' was an elected konchansky headman, who conducted the current affairs of the 'end' under the supervision of the konchansky meeting or Veche, which had administrative power. The Union of Ends formed the community of Veliky Novgorod. Thus, Novgorod was a fairly democratic Republic for its time, a political system that was characterized by the following:

1) a civil community with a broad social base;

2) selectivity of the higher administration;

3) contract with the Prince;

4) developed local self-government.

Consideration of Novgorod civil society cannot be limited to the analysis of the state system and institutions, although, of course, they were its mainstay. Along with the state, there was also private life (family, life, traditions, customs), on which state institutions were based. It should be noted that these issues are poorly studied and described in the scientific literature.

\section{Research by Russian historians and the main results of archaeological excavations}

Russian scientists in the 18 th and 19 th centuries paid sufficient attention to the 
study of the emergence of the state and political institutions in Novgorod. The works of V.N. Tatishchev, N.M. Karamzin, S.M. Solovyov, and V.O. Klyuchevsky are devoted to this problem. In the 20th century, interest in it increased even more. The research of B.D. Grekov, D.A. Vvedensky, A.N. Nasonov, V.L. Yanin, B.A. Rybakov, M.X. Aleshkovsky, A.V. Kuzy, N.E. Nosov, V.F. Andreev, and M.N. Tikhomirov continued what was started by Russian historians of the past centuries. A significant contribution to the development of the topic was made by the I.Y. Froyanov's monograph of Rebellious Novgorod (Fedotov, 1982). However, against the background of a large amount of factual material and many valuable generalizations, the problem of civil society formation in the Ancient Novgorod Republic turned out to be little noticed and meaningful. In addition, it seems that without its analysis, the consideration of Novgorod state and political institutions may become incomplete. In Russian historical science, the everyday and private life of Novgorodians in the period from the 11th to 15 th centuries did not find such a comprehensive coverage. Therefore, the task of any researcher, who undertakes to understand the ancient Novgorod civil society, is to consider the non-state civil life of Novgorodians. Also, we can note the work of modern Russian-in-born scientist Alexander G. Buychik, who made research of democratic characteristics of Ancient Novgorod civil society in the early 21st century (Buychik, 2019).

Literacy, which was widely spread among its population, was of great importance for the development of civil society in the Novgorod medieval Republic. Medieval Novgorodians were the citizens associated with trade deals and stood out for their literacy. This is evidenced by the inscriptions, 'graffiti' scratched with sharp tools on the walls of Novgorod churches. They were made by literate people, and there were many of them among Novgorod merchants and artisans; in some cases, they simply needed literacy for business transactions (Tikhomirov, 1964) [1].

The wide spread of literacy among the Novgorod population is also indicated by a large number of birch bark letters. It is important to emphasize that "most of the letters were private letters, the very existence of which was unknown before the excavations in medieval Russia. All sorts of everyday and business issues were touched upon. Many of the certificates were business documents. The complaints addressed to the government were also found. There were school records, comic texts, and more." (Artsikhovsky, 1964)

Now we can turn to the social structure of Ancient Novgorod society. Already excavations in 1951-1961 found several dozen craft workshops in Novgorod, more than in all other Russian cities totally (Artsikhovsky, 1964). Apparently, a huge part of the city's population was made up of artisans. 
Shoemakers' workshops were the most numerous. The jewelers were in second place. Workshops of bone cutters and blacksmiths were repeatedly met. However, no ordinary forges have been found yet: they were probably located outside the city limits for fire protection reasons. The excavated forges belonged to the specialists, who produced steel for the other blacksmiths.

A large number of artisans engaged in shoemaking was typical for various districts of the city. During the excavations, several hundred thousand pieces of leather shoes were found. This can be compared with the fact that bast shoes are found only once, although the bast was well preserved in Novgorod and is often found. It is obvious that Novgorodians wore leather shoes. There were no purses, as the Russian Chronicles call the poor by the purses. The antithesis of people shod in bast shoes and people shod in leather, retained its significance in Russia until the 20th century. Usually shoes of Novgorodians were pistons from the 10th to the 13th centuries and boots in the 14th and 15th centuries. From other leather products, balls are relatively common. It turns out, Novgorodians loved to play ball.

Novgorod was not a city of traders (merchants), although historians depicted it as such. Its population was not so much merchants as artisans. However, of course, trade was very important there, and the excavations showed it. Archaeologically, objects that originated from different Russian lands, as well as from different Western and Eastern countries, have been identified. In the layer of the 10th century, two large hoards of silver Central Asian coins, minted mainly in Samarkand, were found. A number of birch bark certificates are related in their content to trade. Among them, there are many monetary settlements.

Everyday and private life of Novgorodians were determined, first of all, by Orthodoxy, which was their way of life. Everyday life was closely connected with the rhythm of the Church calendar, which inevitably transferred to the social and political life of medieval Novgorod. Being the moral core Orthodoxy formed moral norms in relation to the power structures: the power of the prince, the posadnik, the Veche self-government.

\section{Conclusion}

Thus, the Ancient Novgorod civil society not only enriched the world practice but also created an original type of civil society. One of the Russian idea's representatives, G. Fedotov, who developed the theory of the Orthodox democratic state, believed that this had already happened once in Russian history, meaning "the creation of a unique Orthodox democracy in Novgorod" (Fedotov, 1982). 


\section{References:}

Artsikhovsky, A.V. (1964). Novgorod the Great according to archaeological data. Novgorod to the 1100th Anniversary of the City: Collection of Articles. Moscow: Nauka. Buychik, A.G. (2019). Unbelievable Ancient Russia: Slavic Democracy: History of society and democracy: before new epoch. USA: Kindle Edition.

Fedotov, G.P. (1982). Collection of articles in 6 vols. Vol. 2: Russia, Europe and us. Paris, 1982.

Froyanov, I.Y. (1992). Mutinous Novgorod. St Petersburg: Publishing House of St Petersburg State University.

Froyanov, I.Y., Yudin, Y.I. (1983). On the historical foundations of the Russian bylinnaya epic. Russian Literature, 2, 93.

Kliuchevsky, V.O. (1906). Course in Russian history. 2nd ed. In 5 vols. Vol. 1. Moscow. Muravyev, V.A., Syromyatnikov, B.I. (1973). About the formation of feudal relations in Ancient Russia. History and Historians. Moscow.

Presnyakov, A.E. (1993). Princely law in Ancient Russia. Essays on the bistory of the the period from 10th to the 12th centuries. Moscow: Nauka.

Rybakov, B.A. (1982). Kievan Rus and the Russian principalities of the 12 th and 13 th centuries. Moscow: Nauka.

Tikhomirov, M.N. (1964). Veliky Novgorod in the history of world culture. Novgorod to the 1100th Anniversary of the City: Collection of articles. Moscow: Nauka

Sergeyevich, V.I. (1973). Veche and the Prince. Russian state structure and management during the Rurikovich period: Historical essays. Moscow; Lectures and research on the ancient history of Russian law, 3rd ed. St Petersburg: Publishing House of M.M. Stasyulevich, 1903; Russian legal antiquities, 2nd ed. with amendments in 2 vols. Vol. 2. St Petersburg: Publishing House of M.M. Stasyulevich, 1900.

Solovyev, S.M. (1960). History of Russia since ancient times in 15 books. Book 2. Vols 3-4. Vol. 3. Moscow: Publishing House of Social and Economic Literature.

Vladimirsky-Budanov, M.F. (1900). Review of the history of Russian law. 3rd Ed. with additions. St Petersburg, Kiev: Nobel Press.

\section{Notes:}

[1] In the scientific literature, a different point of view on this issue expressed, too. So, M.N. Tikhomirov wrote: "The usual version that explains the rescue of Novgorod and Pskov from the Tatar pogroms by the spring rasputitsa, which prevented Batu's hordes from ravaging the Novgorod land, is unconvincing. Who would prevent Batu from waiting for a dry summer or a cold winter that 
bound the Novgorod swamps and rivers to get to Novgorod? After all, Batu did not belong to the precocious generals and, as other examples show, was able to wait. A whole year passed between the conquest of the Great Bulgars and the Tatar invasion of the Ryazan land, and the impenetrable forests and swamps between the Great Bulgarians and the Ryazan land were no less than in the Novgorod land. Novgorod was saved from ruin not by the elements of nature, but by the courage of its defenders".

[2] There are at least three approaches to the social structure of Rus in the period of the 9th to 12th centuries. The most common concept is the development of feudalism (V.V. Mavrodin, B.A. Rybakov, M.N. Tikhomirov, etc.). the point of view is also expressed about the existence of a slave-owning system in Russia during this period. (See, for example: Goremykin, V.I. (1970). On the problem of the history of pre-capitalist societies (based on the materials of ancient Russia). - Minsk). According to I.Y. Froyanov, in Russia of the the period from 11th to the 20th centuries there was a system of 'city volosts', 'city-states' (Froyanov I.Y. (1980). Kievan Rus: Essays on socio-political history. - Leningrad: Publishing House of the Leningrad State University), 'pre-feudal period' understood as 'community without primeval' (Froyanov I.Y.; Yudin Y.I. On the historical foundations of the Russian bylevogo epic. Russian Literature. 1983, Vol. 2. p. 93), the system of "city-states that had a lot in common with the ancient Greek Polis" (Froyanov I.Y.; Dvornichenko A.Y. City-states in Ancient Russia. Formation and Development of Early Class Societies: City and State. Leningrad: Publishing House of the Leningrad State University. 1968, pp. 198311). The latter approach seems to us to be the most justified. Analyzing the prerequisites for the formation and the elements of civil society in Novgorod in the 11th and 12th centuries, we will express a number of arguments in support of this approach.

[3] Russian Pravda was an ancient Russian code of laws containing the norms of oral and written law. The Pravda consisted of the so-called Ancient Pravda published probably in the period of 1015-1016 and the so-called Pravda of the Yaroslavichs (mid-11th century). The extensive edition of Russian Pravda was probably formed in the first third of the 12th century. 